METAL FORMING

Interrelation Between Theory

and Practice 
The Metallurgical Society of AIME Proceedings published by Plenum Press

1968-Refractory Metal Alloys: Metallurgy and Technology Edited by I. Machlin, R. T. Begley, and E. D. Weisert

1969-Research in Dental and Medical Materials Edited by Edward Korostoff

1969-Developments in the Structural Chemistry of Alloy Phases Edited by B.C. Giessen

1971-Metal Forming: Interrelation Between Theory and Practice Edited by A. L. Hoffmanner 


\section{METAL FORMING Interrelation Between Theory and Practice}

Proceedings of a symposium on the Relation Between Theory and Practice of Metal Forming, held in Cleveland, Ohio, in October, 1970

Edited by

A. L. Hoffmanner

Principal Engineer

Materials Technology

Equipment Group of TRW, Inc.

Cleveland, Ohio 
(C) 1971 Springer Science+Business Media New York Originally printed by Plenum Press, New York in 1971 Softcover reprint of the hardcover 1st edition 1971

Library of Congress Catalog Card Number 70-171698

ISBN 978-1-4613-5708-7

DOI $10.1007 / 978-1-4615-1757-3$

ISBN 978-1-4615-1757-3 (eBook) 
METAL FORMING: THE INTERRELATION BETWEEN THEORY AND PRACTICE

A Memorial Volume Dedicated to the Memory of Professor Horace Polakowski

It is infrequent that a man rises in the technical community to successfully contribute to both basic science and commercial technology. Horace Polakowski was one of those rare individuals destined by both ability and desire to significantly contribute to both.

This man not only attained eminence in the world of science as we11 as the world of technology, but 1iterally spanned the globe in his work experience. He was fluent in English, German, Polish, and Russian and had a working knowledge of French and Italian.

He was born on December 4, 1914, in Poland, where in 1938, he obtained a diploma in engineering (mechanical engineering) from the Technical University of Lvov, Poland. His first technical experience was in industrial operations in Poland, a Mannesmann steel tube mill, a stamping and pressing shop, an alloy foundry, large military vehicle repair shops, and in a gray iron foundry. In 1939 he was awarded a fellowship to study at the University of Swansea but was unable to join the Metallurgical Engineering Department until after World War II。 In 1948, he joined the University of Swansea and in 1952 was granted a $\mathrm{Ph} . \mathrm{D}$. in metallurgy. In 1950 he was awarded the Andrew Carnegie Silver Medal by the Iron and Stee 1 Institute in London.

As a stateless person, Dr. Polakowski came to the United States to join the Armzen Company as Development Manager in 1953. Subsequently he joined La Salle Steel Company where he worked prior to becoming a member of the staff of Illinois Institute of Technology. He was appointed a full Professor at IIT in 1958. He published prolifically in many technical areas. In 1965 the University of Wales recognized his important technical contributions and conferred upon Dr. Polakowski a Doctor of Science.

In recent years his interest turned more and more to commercial applications of his extensive background in metalworking. As he so aptly put it he became "a consultant to the world。" Equip- 
ment designed according to his patents have found worldwide acceptance in the roller leveling of strip.

Truly, Dr. Natalis Horace Polakowski made unique contributions to metalworking science and technology. A recitation of his accomplishments unfortunately cannot truly do justice to the flavor of this man who could galvanize an audience, convulse his listeners with laughter, and at the same time bring to bear an incisive and inquiring mind on important technical problems.

This volume is indeed a fitting memorial. Horace Polakowski may have been a stateless person when he landed in the United States on December 28, 1953, but he was an illustrious citizen of the world when he died while returning after delivering a lecture series in Argentina in 1970.

E11iot S. Nachtman

January, 1971 
FOREWORD

On October 21 and 22, 1970, the Shaping and Forming Committee, Institute of Metals Division, The Metallurgical Society of AIME, held a Conference on "The Relation Between Theory and Practice in Metal Forming" at the Sheraton-Cleveland Hotel during the Fall Meeting of AIME in Cleveland, Ohio. This conference was devoted to recent applications of theory to metal forming to establish a milestone in the current ability to predict phenomena during deformation processing and, thereby, demonstrate the utility of theory for process design. The papers were selected by first requesting presentations of relevant recent work from 68 recognized authorities in metal forming which resulted in 17 papers. A subsequent call for papers resulted in the submission of 19 abstracts from which 4 papers were selected. The selection criteria required that the paper coupled theory with practice, and that the work was recent, unpublished and worthy of permanent record. The selection was performed by the Conference Chairman.

The papers in this volume have been organized in accordance with the following subjects:

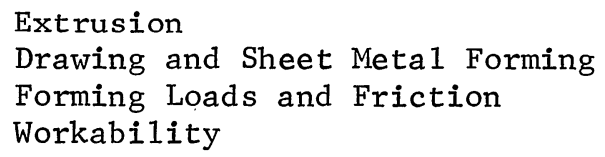

These papers appear to assess the salient recent applications of mechanics to the deformation processing of alloys at the present time, i.e., circa 1970 。 
Taylan Altan, Metalworking Division, Columbus Laboratories, Battelle Memorial Institute, Columbus, Ohio

W. A. Anderson, Physical Metallurgy Division, Alcoa Research Laboratories, New Kensington, Pennsylvania

Betzalel Avitzur, Professor of Metallurgy and Materials Science, Lehigh University, Bethlehem, Pennsylvania

C. Baker, Reynolds Metals Company, Richmond, Virginia

John T. Berry, Department of Mechanical Engineering, University of Vermont, Burlington, Vermont

J. H. Brophy, Pau1 D. Merica Research Laboratory, The Internationa 1 Nicke1 Company, Incorporated

T. Chandra, Department of Metallurgical Engineering, McGil1 University, Montrea1, Canada

H. Darlington, Homer Research Laboratories, Bethlehem Steel Corporation, Bethlehem, Pennsylvania

Vincent DePierre, Air Force Materials Laboratory, MAMN, Wright Patterson Air Force Base, Ohio

M. L. Devenpeck, Edgar C. Bain Laboratory for Fundamenta1 Research, United States Stee1 Corporation, Monroeville, Pennsylvania

R. W. Dunlap, Carnegie Me11on University, Pittsburgh, Pennsylvania

R. C. Gibson, Paul D. Merica Research Laboratory, The Internationa1 Nicke1 Company, Incorporated

H. W. Hayden, Paul D. Merica Research Laboratory, The International Nicke1 Company, Incorporated 
D. O. Hobson, Metals and Ceramics Division, Oak Ridge National Laboratory, Oak Ridge, Tennessee

A. L. Hoffmanner, T R W Incorporated, Cleveland, Ohio

J. J. Jonas, Department of Metallurgical Engineering, McGil1 University, Montrea1, Canada

L. J. Kashar, United States Stee1 Corporation, Monroeville, Pennsylvania

Shiro Kobayashi, Department of Mechanical Engineering, Division of Mechanical Design, University of California, Berkeley, California

E. H. Kottcamp, Jr., Homer Research Laboratories, Bethlehem Steel Corporation, Bethlehem, Pennsylvania

S. A. Levy, Reynolds Metals Company, Richmond, Virginia

Alan T. Male, Westinghouse Astronuclear Laboratories, Pittsburgh, Pennsylvania

H. J. McQueen, Mechanical Engineering, Sir George Williams University, Montrea1, Canada

James A. Mullendore, Chemical and Metallurgical Division, Sylvania Electric Products, Incorporated, Towanda, Pennsylvania

T. E. O'Conne11, Carnegie Mel1on University, Pittsburgh, Pennsylvania

Malcolm H. Pope, Department of Mechanical Engineering, University of Vermont, Burlington, Vermont

H. C. Rogers, Department of Metallurgical Engineering, Drexe1 University, Philadelphia, Pennsylvania

R. W. Rogers, Jr., Physical Metallurgy Division, Alcoa Research Laboratories, New Kensington, Pennsylvania

George Sau1, Air Force Materials Laboratory, MAMN, Wright Patterson Air Force Base, Ohio

John A. Schey, Department of Materials Engineering, University of Illinois, Chicago Circle, Chicago, Illinois

Aly H. Shabaik, Assistant Professor of Engineering, University of California, Los Angeles, California 
Oleg D. Sherby, Department of Materials Science, Stanford University, Stanford, California

Conrad M. Young, Department of Materials Science, Stanford University, Stanford, California

Z. Zimerman, Homer Research Laboratories, Bethlehem Stee1 Corporation, Bethlehem, Pennsylvania 
CONTENTS

\section{EXTRUSION}

Study of Flow Through Conical Converging Dies . . . . . 1

B. Avitzur

Selection of Operating Parameters to Prevent Centra1 Bursting Defects During Cold Extrusion . . . . . . .

Z. Zimmerman, H. Darlington, and E。H。Kottcamp, Jr。

The Effect of Material Properties on Tension Zone

and Boundary Shear-Stress in Extrusion . . . . . . .

A.H. Shabaik

Application of Visioplasticity Techniques to

Axisymmetric Extrusions . . . . . . . . . . . •

R.E. Medrano, P. P. Gillis, C. P. Hinesley, and $\mathrm{H}$ 。Conrad

The Extrusion of Rate Sensitive Materials . . . . . . $\mathrm{J}$. J. Jonas and $\mathrm{T}$. Chandra

Deformation Criteria for Predicting the Cold-Extrusion

Pressures of Metals . . . . . . . . . . . . .

L. J. Kashar, R. W. Dunlap, and T.E. O'Connel1

DRAWING AND SHEET METAL FORMING

The Effect of Homogeneity on the Formability of 7000 Series Aluminum Alloys for Cartridge Cases . . . • S. A. Levy and C. Baker

Effect of Plastic Anisotropy on Drawing Characteristics of Aluminum Alloy Sheet . . . . . . .

$\mathrm{R}$. W. Rogers, Jr., and $\mathrm{W}$. A. Anderson 
Analyses of Deformation and Texture as Functions

of Fabrication in Mandre1-Drawn Tubing

D. 0. Hobson

Experimental Evaluation of Theoretically

Ideal Drawing Dies

M. L. Devenpeck

The Application of the Avitzur Upper Bound Equation

to Tungsten Wire Drawing and Its Use in Die-Line

Design

J. A. Mullendore

\section{FORMING LOADS AND FRICTION}

Computer Simulation to Predict Load, Stress, and Metal Flow in an Axisymmetric Closed-Die Forging . . . . . . Taylan Altan

The Validity of Simulating Tests in Evaluating

Lubricants for Deformation Processes . . . . . . .

J.A. Schey

A New Method for the Determination of Material Flow

Stress Values under Metalworking Conditions . . . . . .

G. Saul, Alan T. Male, and V. DePierre

Force Requirements and Friction in Warm Working

Operations . . . . . . . . . . . . . . . . 。

John T. Berry and Malcolm H. Pope

\section{WORKABILITY}

Theories and Experiments on Friction, Deformation, and Fracture in Plastic Deformation Processes . . . . . Shiro Kobayashi

The Use of Workability Test Results to Predict

Processing Limits . . . . . . . . . . . . . .

A. L. Hof fmanner

Hot Workability Testing Techniques . . . . . . . 。 H. J. McQueen and J. J. Jonas 
Simulation of Extrusion Structures by Means of Torsion Testing for a High Strength Nicke1-Base

Alloy, Udimet 700 . . . . . . . . . . . . 。

C. M. Young and O. D. Sherby

Prediction and Effects of Material Damage During

Deformation Processing . . . . . . . . . . . .

H. C. Rogers

The Relationship Between Superplasticity and

Formability . . . . . . . . . . . . . . .

Wayne Hayden, R. C. Gibson, and J.H. Brophy

Index . . . . . . . . . . . . . . . . . . 